\title{
THE AMENITY VALUE OF CLIMATE TO GERMAN HOUSEHOLDS
}

Katrin REHDANZ ${ }^{*}$ and David Maddison ${ }^{b}$

${ }^{a}$ Centre for Marine and Climate Research, Hamburg University, Hamburg, Germany

${ }^{b}$ Institute of Economics, University of Southern Denmark, Odense, Denmark

* Corresponding author: ZMK, Troplowitzstrasse 7, 22529 Hamburg, Germany, rehdanz@dkrz.de

\begin{abstract}
This study uses the hedonic approach to measure the amenity value of climate in Germany. Unlike in earlier research separate hedonic wage and house price regressions are estimated for relatively small geographic areas and formal tests undertaken to determine whether the coefficients describing the impact of climate variables are homogenous across these areas. Evidence suggests that German households are compensated for climate amenities mainly through hedonic housing markets. Given that climate is largely unproductive to industry and few industries spend more on land than labour this is consistent with what theory would predict. Throughout Germany house prices are higher in areas with higher January temperatures, lower July temperatures and lower January precipitation. In East Germany wages are higher in areas with higher January precipitation. The full implicit price of climate variables however is very uncertain.
\end{abstract}

Keywords: Climate Change; Germany; Hedonic Pricing

JEL Classification: Q29; R29 
THE AMENITY VALUE OF CLIMATE TO GERMAN HOUSEHOLDS

\section{$\underline{\text { List of Contents }}$}

1 Introduction 2

2 Empirical Analysis 6

3 Discussion 12

4 Conclusions $\quad 15$

Acknowledgements $\quad 16$

$\begin{array}{ll}\text { References } & 17\end{array}$ 


\section{Introduction}

Recent years have witnessed a bourgeoning number of studies investigating the consequences of climate change. Research work has examined changes in productivity in sectors like agriculture and forestry where climate plays an obvious and important role. Other papers have attempted to estimate the costs of protecting low lying but densely populated coastal areas. Attention has also been devoted to the costs of extreme events and hurricane intensity. Researchers have considered the health impacts of changes in the frequency of heat waves and of changes in the distribution of disease vectors. The ultimate goal of this and related research is presumably to compare the costs of preventing climate change to the benefits (Pearce et al, 1996; Intergovernmental Panel on Climate Change, 1998; Intergovernmental Panel on Climate Change, 2001; and more recently Tol 2002a; and Tol 2002b).

One important sector that will be impacted by climate change but has not yet attracted sufficient attention is the household sector. This neglect is not due to any consensus that the direct impact of climate change on households will be negligible. Climate determines the need for heating and cooling. It affects clothing, housing and nutritional expenditures and dictates recreational possibilities. Climate affects human health. Certain types of climate are also known to promote a sense of happiness and the sorts of fauna and flora supported by particular sorts of climate are also a source of pleasure to households. Considering the importance of the household sector information on the overall value of climate amenities to households would in our opinion, make a significant contribution to the overall assessment of climate change impacts.

One methodology that suggests itself for this purpose is the hedonic technique. Fundamental to the hedonic approach is the assumption that households are attracted to those localities offering preferred combinations of amenities. Households should expect to pay higher property prices if the house is located in a preferred area and they might also accept different wage rates. Information on the implicit value placed on households can therefore be obtained by examining households' locational choice. Compared to other methodologies the strength of the hedonic approach in this context is that it compares areas where it is assumed that all the myriad cost minimising adaptations to climatic differences have already occurred. Rosen 
(1974) provided the theoretical foundation of the technique. In his seminal paper he illustrated how individual willingness to pay for environmental goods can be derived from observable market prices. Roback (1982) is another major contribution to the theoretical literature on hedonic analysis. She was the first to note that across different geographical locations there generally have to exist both compensating wage and house price differentials and that amenity values can be capitalised into either or both of these. The critical assumptions of the hedonic approach are well known (e.g. Palmquist, 1991) and, with the exception of one particular assumption, not further discussed here.

Although a large number of hedonic studies have included climate variables for purposes incidental to the main aims of the study only a handful of studies have deliberately set out to measure the amenity value of climate to households using the hedonic technique. Hoch and Drake (1974) found evidence of the influence of climate on wages for different worker categories in the United States. Englin (1996) investigated the amenity value of rainfall as revealed in the housing market. He found that households prefer less rainfall to more but that holding annual rainfall constant households prefer a greater seasonal variation. Nordhaus (1996) used a hedonic wage regression corrected for differences in the cost of living to estimate the amenity value of January, April, July and October averages for temperature and precipitation. Cragg and Kahn (1997) and Cragg and Kahn (1999) estimate the demand for climate amenities using both the hedonic technique as well a technique that analyses the locational choice of migrants. Outside the United States Maddison and Bigano (2003) investigate the amenity value of climate of Italy using regional averages for expected after tax household labour income net of housing as the dependent variable. They find that Italians prefer a drier climate during the winter months and lower summertime temperatures.

A key aspect of previous research employing the hedonic technique is that researchers have found it necessary to estimate hedonic regressions over large geographic areas to identify statistically significant effects of climate on house prices and wage rates. This is because climate variables are undeviating over relatively large distances. But at such distances one of the underlying assumptions of the hedonic technique, namely the existence of a unified market for housing and employment within which the net benefits of different locations are 
eliminated, becomes untenable. As first pointed out by Straszheim (1974) researchers risk biased results by attempting to fit a single hedonic price function to what are in effect separate hedonic price schedules. The fact that researchers attempting to value a range of other environmental amenities have encountered evidence of structural instability at geographical distances much less than those over which significant differences in climate can be observed (e.g. Schnare and Struyk, 1976; and Michaels and Smith, 1990) invites the question of whether previous hedonic climate studies have in fact succeeded in measuring what they intended to measure.

This study uses the hedonic price approach to investigate household preferences for climate in Germany. Although it is the most populous country in the European Union we are not aware of any research attempting to determine the value of climate amenities to households in Germany. Indeed, although environmental issues and in particular climate change are taken very seriously in Germany, hedonic valuation studies of any kind are surprisingly scarce. A review by Navrud (1999) of European valuation studies completed between 1992 and 1999 revealed that Germany is one of the countries having the least valuation studies of any kind. Existing studies using the hedonic price method in Germany have looked mainly at noise and air pollution (e.g. Holm-Müller et al, 1991).

The data for this exercise is drawn from the German socio-economic panel survey. The German socio-economic panel is a survey of private households and individuals providing detailed information on housing, occupational and socio-economic characteristics of households and individuals. For the 1999 survey the panel offers additional information on neighbourhood characteristics important for the conduct of a hedonic analysis.

Unlike earlier research we estimate hedonic regressions for relatively small geographic areas and then formally test whether the coefficients describing the impact of climate variables on house prices and wage rates are homogenous across these regions. If the null hypothesis of parameter homogeneity is not rejected these coefficient estimates are combined to yield an improved estimate of the underlying effect. If the null hypothesis of parameter homogeneity is rejected then steps are taken to identify smaller geographical areas over which the assumption 
of parameter homogeneity is not rejected. Such an approach is especially warranted in a country only recently reunited. This can be compared with the work of Nordhaus (op cit) and Maddison and Bigano (op cit) who effectively assume a national market for housing and labour whilst including dummy variables for States or in the case of the latter paper, the islands of Sicily and Sardinia.

A second distinguishing feature of the paper is that it employs climate data at a far higher level of geographical resolution. The papers by Cragg and Kahn (op cit) and Hoch and Drake (op cit) for example assume that climate is homogenous at the level of the State. In this paper by contrast Germany, a country equal in size to Montana and half the size of Texas, is divided into more than four hundred climatic zones. Although the climate in Germany is mostly temperate and not nearly as diverse as for example Italy or the United States, it is influenced by the different geographical and topographical characteristics of its regions. Due to the effect of the sea the climate of the North German plain and the Baltic coast is relatively unvarying. The combination of high levels of sunshine and high rainfall results in a green and fertile landscape. The climate in Central and Southern Germany is more varied due to topographical features of these regions. In Bavaria the climate is similar to the Austrian Alps with cold winters and frequent snowfall. In Rhineland Palatine and Saarland in South Western Germany by contrast the climate is held to be particularly pleasant.

For Germany climate models predict as a consequence of projected increased greenhouse gas emissions an increase in temperature of about $4^{\circ} \mathrm{C}$ by 2100 with a greater degree of warming expected in the south of the country. Very warm summers will become more frequent and very cold winters increasingly rare. Summers are expected to become drier over all of Germany whilst winter is likely to become wetter (Hulme and Shead, 1999).

Before moving to the empirical analysis it is worthwhile remarking that the hedonic technique is not the only valuation methodology by which researchers have attempted estimate the amenity value of climate to households. In an interesting paper Frijters and Van Praag (1998) analyse self-reported happiness in Russia and find that this is greatly influenced by the climate of the location in which the individual lives. Maddison (2003) uses the household production 
function approach to explain differences in international patterns of consumption partially in terms of climatic differences, deriving an estimate of the welfare impact of climate change. In addition, a number of studies on migration have found an important role for climate (e.g. Graves, 1980; and Cushing, 1987). Although such studies are clearly interesting since they focus on the process by which the net benefits offered by particular locations are eliminated, because of their lack of welfare-theoretic underpinnings they do not admit making inferences regarding the amenity value of climate.

\section{Empirical Analysis}

Most of the data used in this study was provided by the German socio-economic panel survey. Since 1984 the survey has provided annual information on housing, and on the occupation, employment history and earnings of individuals. In 1990 it was extended to include former East Germany. In addition to a stable set of core questions, each year the survey focuses on a special topic and the 1999 dataset included detailed information on neighbourhood characteristics. In order to take advantage of this information the analysis in this paper relies exclusively on the 1999 survey. Currently the data is made available only on the district level (specifically Kreise and kreisfreie Städte) but with few exceptions it is plausible to assume that individuals living within these small geographic areas generally enjoy the same climate. In total 418 different Kreise or kreisfreie Städte are included in the following analysis. Each of these districts is assigned to one of 16 different Federal States (or Bundesländer). These are illustrated in figure 1.

Mitchell et al (2003) provide data on temperature and precipitation. Climate variables measured as monthly averages were matched to the respective Kreis or kreisfreie Stadt using MapInfo. Across these politically defined districts January mean temperatures range from $3.9^{\circ} \mathrm{C}$ to $2.1^{\circ} \mathrm{C}$ whilst July mean temperatures range from $13.1^{\circ} \mathrm{C}$ to $18.1^{\circ} \mathrm{C}$. Precipitation in January ranges from $28 \mathrm{~mm}$ to $77 \mathrm{~mm}$ whilst July precipitation ranges from $51 \mathrm{~mm}$ to $158 \mathrm{~mm}$.

Following Roback (op cit) hedonic regressions were estimated both for house prices and wage rates. Dealing first with the hedonic house price regression, the logarithm of monthly rental 
costs per square metre was regressed on a number of environmental characteristics and structural attributes of the properties. Note that for owners, the survey provides self-reported imputed rents rather than actual rents. Hoffmann and Kurz (2002) state that the rental housing market in Germany is generally less regulated compared to many other European countries. We excluded from our analysis households living in residential home, student halls and hostels.

January temperature and precipitation and July temperature and precipitation are included in the regression alongside latitude and longitude, unemployment rates and population density. These variables do not vary at the level of the Kreise or kreisfreien Städte. Unemployemnt and population density are taken from Statistisches Bundesamt Deutschland (2001). The inclusion of both latitude and longitude in the hedonic regression equations may seem injudicious since both are correlated with the climate variables. Latitude however has a potentially important role in controlling for variations in daylight hours across the seasonal cycle whilst longitude further emphasises the robust nature of the results.

In terms of structural attributes the model includes dummy variables describing the property's state of renovation, the date of its construction, as well as the type of property (flat, detached house etc). The model controls for the size of the property in square metres, as well as whether the house has heating, a garden and a balcony. Controls are also included for the size of the town or city in which the property is located as well as variables indicating the distance to the nearest large city and the nearest park. Dummy variables indicate whether the property is in a predominantly residential, industrial or commercial area.

Turning to the hedonic wage rate regression, the dependent variable was the logarithm of the hourly wage rate net of tax. Apart from climate variables, latitude, longitude, population density and unemployment, the regression includes controls for a large number of worker and employer characteristics. These include gender, age and its squared value, the number of years with the current employer, possession of a degree, years of education, marital status, disability status and whether the worker is a trainee. Dummy variables identify the occupational grade of the worker (manager, professional, labourer etc) the industry in which 
they were working (agriculture, service sector, manufacturing etc) and the size of the employer. Data on union membership, although generally included in hedonic wage regressions, is unfortunately not provided by the survey.

In order to account for the possible correlation of residuals when observations are taken from the same Kreis or kreisfreien Stadt, the standard errors of the hedonic house price and wage rate regressions were adjusted for clustering on the level of the Kreise and kreisfreien Städte. The effect is to increase the standard errors of the parameter coefficients. This procedure also leads to robust variance estimates in the face of heteroscedasticity.

In total 5,366 observations are included in the house price regression whilst 6,862 observations are included in the wage regression. Separate regressions are run for 12 different regions. These regions are equivalent to the Bundesländer except that Hamburg and Schleswig-Holstein are included as one region as are Lower Saxony and Bremen; Rhineland Palatine and Saarland; and Brandenburg and Berlin. These contain varying numbers of Kreise and kreisfreie Städte. Bavaria, the largest of these regions, contains 87 Kreise and kreisfreie Städte. To avoid presenting a large number of regressions only the coefficients relating to the climate variables are presented in table 1 and table 2. Because these regressions were estimated over areas in which only limited variation in climate is observed it is unsurprising that few of the coefficients are statistically insignificant. In the following section however these coefficients are combined using meta-analytical techniques to shrink the associated uncertainty.

Only after experimenting with different ways of describing the climate was it determined that the single best description of climate in both the hedonic wage and house price regression was provided by the use of January and July averages. The hedonic analysis of Italy presented by Maddison and Bigano (op cit) also found that representing the climate by January and July averages provided the best fit to their data. In the context of the United States Cushing (op cit) investigated the determinants of population migration decisions using different specifications of temperature and found that the warmest and coldest and wettest and driest months provided the best description of climate whereas annual averages were the least preferred. We also tried 
including higher order terms for the climate variables but discovered that even in regressions including all Bundesländer that they afforded no significant explanatory power. Note also that three different transformations of the dependent variable were considered: the linear, semilogarithmic and inverse models. For both the wage and house price regression the semilogarithmic model provided the most consistent results judging by tests for functional form.

Figure 1. The Federal States of Germany

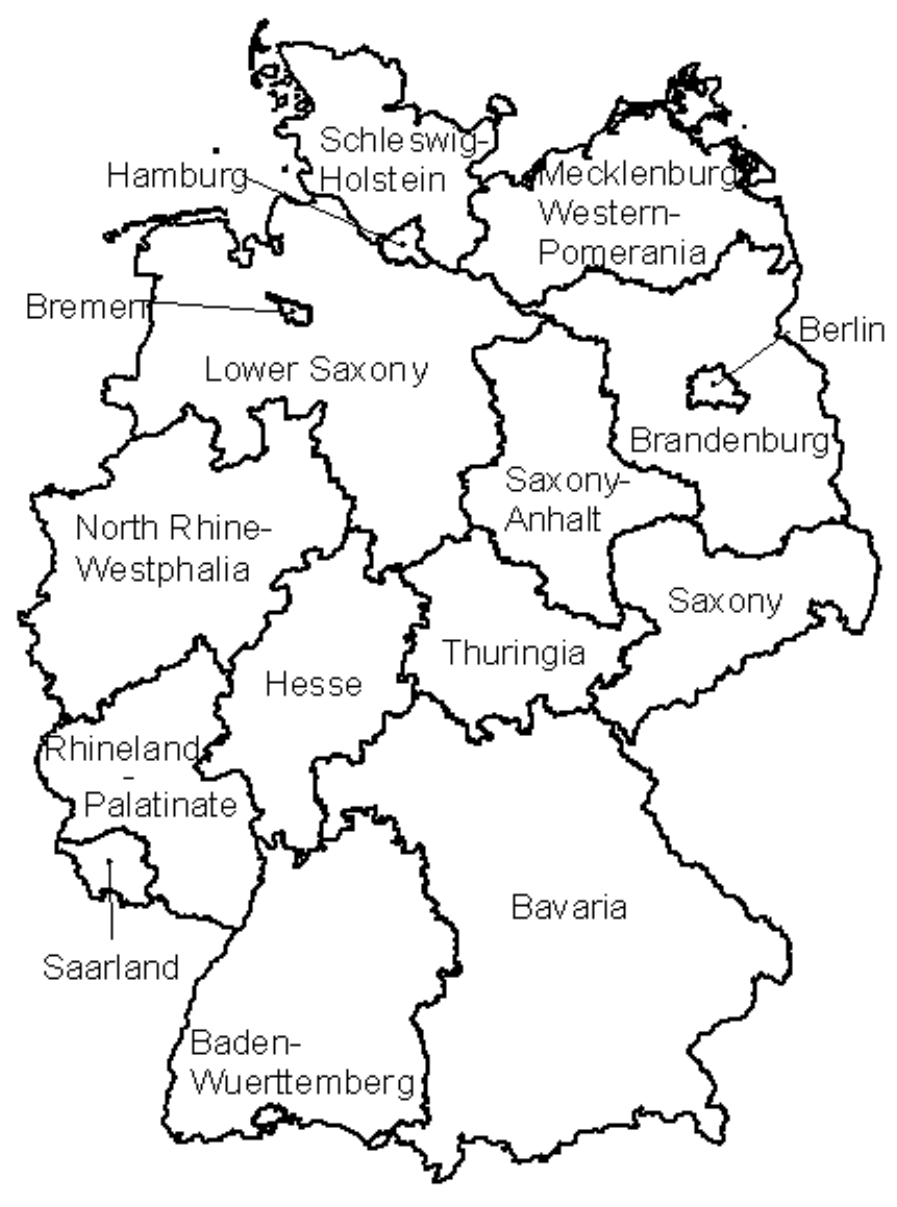


Table 1. Parameter Homogeneity among the Coefficients from the House Price Regressions

\begin{tabular}{|c|c|c|c|c|}
\hline & $\begin{array}{l}\text { January } \\
\text { Temperature }\end{array}$ & $\begin{array}{l}\text { July } \\
\text { Temperature }\end{array}$ & $\begin{array}{l}\text { January } \\
\text { Precipitation }\end{array}$ & $\begin{array}{l}\text { July } \\
\text { Precipitation }\end{array}$ \\
\hline $\begin{array}{l}\text { Schleswig-Holstein and } \\
\text { Hamburg }\end{array}$ & -0.348 & -0.238 & 0.00795 & 0.000948 \\
\hline Lower Saxony and Bremen & 0.19 & -0.188 & -0.0108 & 0.00533 \\
\hline North Rhine-Westphalia & 0.239 & -0.151 & -0.00216 & 0.00324 \\
\hline Hesse & 0.0794 & -0.116 & -0.00824 & -0.0122 \\
\hline $\begin{array}{l}\text { Rhineland-Palatine and } \\
\text { Saarland }\end{array}$ & 0.145 & -0.0593 & 0.00116 & 0.00246 \\
\hline Baden-Wuerttemberg & -0.0287 & 0.0737 & $-0.0083 *$ & 0.00367 \\
\hline Bavaria & $0.377^{* *}$ & $-0.332^{* *}$ & $-0.0166^{*}$ & -0.00333 \\
\hline $\begin{array}{l}\text { Berlin and } \\
\text { Brandenburg }\end{array}$ & -0.0266 & 0.0945 & 0.0188 & 0.00138 \\
\hline $\begin{array}{l}\text { Mecklenburg Western- } \\
\text { Pomerania }\end{array}$ & -0.0226 & -0.0246 & -0.00722 & 0.00394 \\
\hline Saxony & 0.147 & 0.0847 & 0.0153 & 0.00412 \\
\hline Saxony-Anhalt & $0.769^{*}$ & $-0.651^{*}$ & -0.00135 & -0.0117 \\
\hline Thuringia & -0.228 & 0.272 & -0.035 & 0.0427 \\
\hline $\begin{array}{l}\text { All Germany Parameter } \\
\text { Homogeneity Test }\end{array}$ & $\begin{array}{l}\chi^{2}(11)= \\
13.53\end{array}$ & $\begin{array}{l}\chi^{2}(11)= \\
19.11\end{array}$ & $\begin{array}{l}\chi^{2}(11)= \\
8.42\end{array}$ & $\begin{array}{l}\chi^{2}(11)= \\
9.84\end{array}$ \\
\hline $\begin{array}{l}\text { All Germany Variance } \\
\text { Weighted Estimate }\end{array}$ & $0.155^{* *}$ & $-0.094 *$ & $-0.006^{* *}$ & 0.001 \\
\hline
\end{tabular}

Note: Significance at the five-percent level is indicated by * and significance at the onepercent level is indicated by **. 
Table 2. Parameter Homogeneity among the Coefficients from the Wage Rate Regressions

\begin{tabular}{|c|c|c|c|c|}
\hline & $\begin{array}{l}\text { January } \\
\text { Temperature }\end{array}$ & $\begin{array}{l}\text { July } \\
\text { Temperature }\end{array}$ & $\begin{array}{l}\text { January } \\
\text { Precipitation }\end{array}$ & $\begin{array}{l}\text { July } \\
\text { Precipitation }\end{array}$ \\
\hline $\begin{array}{l}\text { Schleswig-Holstein and } \\
\text { Hamburg }\end{array}$ & -2.913 & 3.185 & 0.0229 & 0.093 \\
\hline Lower Saxony and Bremen & -0.576 & 0.803 & 0.0491 & -0.035 \\
\hline North Rhine-Westphalia & 0.0834 & -0.144 & -0.012 & $0.0204 * *$ \\
\hline Hesse & -0.681 & 0.538 & 0.0079 & -0.00982 \\
\hline $\begin{array}{l}\text { Rhineland-Palatine and } \\
\text { Saarland }\end{array}$ & -0.384 & -0.0128 & -0.00799 & 0.00416 \\
\hline Baden-Wuerttemberg & 0.105 & 0.00526 & -0.00692 & 0.00364 \\
\hline Bavaria & 0.232 & -0.126 & 0.0132 & -0.00442 \\
\hline $\begin{array}{l}\text { Berlin and } \\
\text { Brandenburg }\end{array}$ & 0.0332 & 0.141 & 0.014 & 0.0301 \\
\hline $\begin{array}{l}\text { Mecklenburg Western- } \\
\text { Pomerania }\end{array}$ & 0.0677 & $-0.384 * *$ & 0.0031 & 0.0398 \\
\hline Saxony & 0.405 & 0.0898 & $0.0415^{* *}$ & -0.00278 \\
\hline Saxony-Anhalt & -1.0343 & $1.515^{* *}$ & $0.0873^{* *}$ & -0.0376 \\
\hline Thuringia & 1.14 & -1.413 & -0.00518 & -0.0197 \\
\hline $\begin{array}{l}\text { All Germany Parameter } \\
\text { Homogeneity Test }\end{array}$ & $\begin{array}{l}\chi^{2}(11)= \\
13.91\end{array}$ & $\begin{array}{l}\chi^{2}(11)= \\
28.06^{* *}\end{array}$ & $\begin{array}{l}\chi^{2}(11)= \\
28.56^{* *}\end{array}$ & $\begin{array}{l}\chi^{2}(11)= \\
22.93^{*}\end{array}$ \\
\hline $\begin{array}{l}\text { All Germany Variance } \\
\text { Weighted Estimate }\end{array}$ & 0.063 & -0.074 & 0.000 & 0.002 \\
\hline $\begin{array}{l}\text { West Germany Parameter } \\
\text { Homogeneity Test }\end{array}$ & $\chi^{2}(6)=8.39$ & $\chi^{2}(6)=9.88$ & $\chi^{2}(6)=8.49$ & $\begin{array}{l}\chi^{2}(6)= \\
14.53^{*}\end{array}$ \\
\hline $\begin{array}{l}\text { West Germany Variance } \\
\text { Weighted Estimate }\end{array}$ & 0.053 & 0.003 & -0.004 & 0.003 \\
\hline $\begin{array}{l}\text { West Germany excl. North } \\
\text { Rhine-Westphalia Parameter }\end{array}$ & $\chi^{2}(5)=8.45$ & $\chi^{2}(5)=9.16$ & $\chi^{2}(5)=7.40$ & $\chi^{2}(5)=6.44$ \\
\hline
\end{tabular}




\begin{tabular}{|l|l|l|l|l|}
\hline Homogeneity Test & & & & \\
\hline $\begin{array}{l}\text { West Germany excl. North } \\
\text { Rhine-Westphalia Variance } \\
\text { Weighted Estimate }\end{array}$ & 0.043 & 0.035 & -0.002 & -0.001 \\
\hline $\begin{array}{l}\text { East Germany Parameter } \\
\text { Homogeneity Test }\end{array}$ & $\chi^{2}(4)=5.43$ & $\begin{array}{l}\chi^{2}(4)= \\
15.52^{* *}\end{array}$ & $\chi^{2}(4)=3.64$ & $\chi^{2}(4)=7.97$ \\
\hline $\begin{array}{l}\text { East Germany Variance } \\
\text { Weighted Estimate }\end{array}$ & 0.115 & -0.218 & $0.045^{* *}$ & -0.002 \\
\hline
\end{tabular}

Note: Significance at the five-percent level is indicated by * and significance at the onepercent level is indicated by **.

\section{Discussion}

The parameter homogeneity test results for the housing regressions indicate that the effects of climate on house prices are homogenous over all Germany. Note that the tests for parameter homogeneity involve the use of the chi-squared test statistic described in Hedges and Olkin (1985). There are also examples of individual Bundesländer (most notably for the largest Bundesland, Bavaria) within which climate variables have a statistically significant effect. The variance-weighted estimates (once more for the relevant formulae see Hedges and Olkin, op cit) indicate that there is a highly significant effect of January temperature and January precipitation. A significant effect for July temperatures is also observed but July precipitation is not significant. Judging by evidence from housing markets it appears that German households prefer drier, warmer winters and slightly cooler summers.

The results for the wage regressions by contrast are more convoluted. Once again there are examples of individual Bndesländer for which the climate variables exercise a statistically significant effect on wage rates especially in East Germany. The hypothesis of parameter homogeneity is rejected for precipitation in July and strongly rejected for both July temperature and January precipitation for all Germany. Even separating the estimates for West Germany and East Germany does not entirely eliminate the problem parameter heterogeneity: the test for parameter homogeneity is rejected for July precipitation for West Germany. The reason for coefficient heterogeneity appears to be the result for North Rhine- 
Westphalia, the region bordering Belgium and the Netherlands and bisected by the river Rhine. The estimate for July precipitation in North Rhine-Westphalia is highly significant suggesting that workers require compensation for working in Kreisen or kreisfreien Städten with higher rainfall. Excluding this region the test for parameter homogeneity is passed but none of the variance weighted estimates describing the effects of climate on wage rates are significant.

The parameter homogeneity tests for the effects of climate on wage rates in East Germany also strongly reject the pooling of coefficients for July temperatures. The results for January precipitation however can be combined and the variance-weighted estimate is highly significant and suggests that workers in East Germany require compensation for precipitation in January.

Given the fact that compensation for climate amenities appears to occur mainly through the hedonic housing market it is helpful to recollect the results of the theoretical model of Roback (op cit). According to her model the sign of the wage and rent gradient with respect to the level of an amenity depends on whether the amenity is productive to companies or attractive only to households. If a company's production costs are not affected by the level of the environmental amenity and firms are mainly labour using rather than land using then the hedonic house price gradient is positive with respect to the level of the amenity whilst wages are not affected by the level of the amenity. Insofar as it is, with the exception of agriculture, difficult to think of many productive activities in Germany that are dependent upon climate or are intensive in the use of land the empirical results uncovered in this paper appear consistent with what theory would predict.

The final step is to calculate the full implicit price for climate variables (i.e. the implicit price of climate variables accounting for the fact that households might be compensated through both housing and labour markets). Implicit prices are calculated for Hamburg, Frankfurt (on the Main) and Munich. These cities are all located in West Germany but not in the Bundesland of North Rhine-Westphalia. The parameter estimates obtained in tables 1 and 2 are used to determine what fraction of annual household housing expenditures and what fraction of annual 
household labour income represents compensation for climate amenities. Note that annual household labour income is calculated by multiplying the average number of workers per household by the fraction of those workers in employment and then multiplying by the average net wage per hour and the number of hours worked per employed person per year. These calculations are performed at the level of the Kreise and kreisfreien Städte except for the number of workers per household, which is assumed to be 0.96 in all locations (Statistisches Bundesamt Deutschland, 1999). A probability distribution for the implicit price of climate variables is constructed and presented in table 3.

This table serves to illustrate the great uncertainties associated with the welfare impacts of climate change. These arise largely because of uncertainties regarding the extent to which households are compensated for climate amenities through labour markets and also because in some instances the gradient of the hedonic house price function and the gradient of the hedonic wage rate function, taken with respect to the level of a particular climate amenity, share the same sign. For example higher January temperatures are associated with higher house prices as well as higher wages. Note however that there is no theoretical requirement that the gradient of the hedonic house price function and the gradient of the hedonic wage rate function should be differently signed (Roback, op cit). All that can be gleaned from table 3 is that households in each of the three cities analysed are more likely to view the higher July temperatures that climate change threatens as a disamenity rather than as an amenity. Uncertainty regarding future emissions of greenhouse gases combined with the fact that different climate models predict different climate change scenarios further increases the range of possible outcomes.

Given the fact that most individuals are unlikely to be aware of differences in the frequency of extreme events offered by different locations, there is also uncertainty regarding whether individuals preferences for avoiding such risks can be identified through housing and labour market price differentials. This is of concern since climate change is expected to increase the frequency of such events. There is nevertheless the potential to use the hedonic approach to value for example the floods that have occurred in Germany during the last few years and which many people blamed on climate change. Houses located in areas likely to be flooded are 
expected to be less expensive compared to those not being at risk. Whilst this might be an interesting study for the future unfortunately the data applied for our study is available on the district level and not therefore adequate to test for this relationship. Nevertheless we feel that the numbers presented in this paper give a first impression of how sensitive German households are to the everyday implications of climate, if not necessarily to extreme events.

Table 3. The 5th and 95th Percentiles of the Implicit Price of Climate Variables

\begin{tabular}{|c|c|c|c|c|c|c|}
\hline & \multicolumn{2}{|l|}{ Hamburg } & \multicolumn{2}{|c|}{ Frankfurt (on the Main) } & \multicolumn{2}{|l|}{ Munich } \\
\hline & $\begin{array}{l}5 \text { th } \\
\text { Percentile }\end{array}$ & $\begin{array}{l}\text { 95th } \\
\text { Percentile }\end{array}$ & $\begin{array}{l}\text { 5th } \\
\text { Percentile }\end{array}$ & $\begin{array}{l}95^{\text {th }} \\
\text { Percentile }\end{array}$ & $\begin{array}{l}\text { 5th } \\
\text { Percentile }\end{array}$ & $\begin{array}{l}\text { 95th } \\
\text { Percentile }\end{array}$ \\
\hline $\begin{array}{l}\text { January } \\
\text { Temperature } \\
\left(\mathrm{DM} /{ }^{\circ} \mathrm{C}\right)\end{array}$ & $-5,855$ & 6,780 & $-5,646$ & 6,868 & $-5,942$ & 7,802 \\
\hline $\begin{array}{l}\text { July } \\
\text { Temperature } \\
\left(\mathrm{DM} /{ }^{\circ} \mathrm{C}\right)\end{array}$ & $-7,865$ & 3,392 & $-7,873$ & 3,270 & $-8,786$ & 3,439 \\
\hline $\begin{array}{l}\text { January } \\
\text { Precipitation } \\
\text { (DM / mm) }\end{array}$ & -234 & 219 & -238 & 212 & -272 & 223 \\
\hline $\begin{array}{l}\text { July } \\
\text { Temperature } \\
\text { (DM / mm) }\end{array}$ & -121 & 209 & -122 & 210 & -137 & 237 \\
\hline
\end{tabular}

Note: One Deutsche Mark is worth 1.95583 Euros.

\section{Conclusions}

This study has illustrated the extent to which German households' preferences for climate amenities are capitalised into wages and house prices. Estimates derived from the hedonic house price regressions suggest that households pay a substantial premium for living in areas characterised by higher temperatures during January and lower temperatures during July. Higher levels of precipitation in January are associated with lower house prices and, in East Germany, higher wages. All these estimates were derived without making implausible assumptions about the geographical extent of housing and labour markets. Unfortunately when the full implicit price of climate variables is computed it is seen that there are great uncertainties regarding the possible impact of climate change on German households. Future 
research might care to investigate the amenity value of changes in other climate variables such as sunshine and snowfall.

It would be interesting to use the hedonic technique to investigate the effects of extreme events on property prices. Although it is unlikely that households consider such events before making choices relating to location, it might be that last year's floods have affected property prices in low-lying areas. Although examining such effects would require more detailed information than is currently available in the German socio-economic panel survey it nonetheless presents an interesting possibility for a future case study.

\section{Acknowledgements}

We would like to thank the GSOEP group for making their dataset available and especially Katharina Spiess and Gundi Knies for their assistance during our stay in Berlin. We are also grateful to Hanne Breitkreuz, Markus Erhard, Andrè Krebber and Malte Schoon for their help arranging the data set. The European Commission Research DG funded project INTEGRA (HPMT-GH-01-00373-04), the Berufungsfond of the BWF and the DIW provided financial support. All errors and opinions are ours. 


\section{References}

Cragg, M. and Kahn, M. (1997) New Estimates of Climate Demand: Evidence from Location Choice Journal of Urban Economics 42: 261-284.

Cragg, M. and Kahn, M. (1999) Climate Consumption and Climate Pricing from 1940 to 1990 Regional Science and Urban Economics 29: 519-539.

Cushing, B. (1987) A Note on Specification of Climate Variables in Models of Population Migration Journal of Regional Science 27: 641-649.

Englin, J. (1996) Estimating the Amenity Value of Rainfall Annals of Regional Science 30: 273-283.

Frijters, P and Van Praag, B. (1998) The Effects of Climate on Welfare and Well Being in Russia Climatic Change 39: 61-81.

Graves, P. (1980) Migration and Climate Journal of Regional Science 20: 227-237.

Hedges, L. and Olkin, I. (1985) Statistical Methods for Meta-Analysis Academic Press: San Diego.

Hoch, I. and Drake, J. (1974) Wages, Climate, and the Quality of Life Journal of Environmental Economics and Management 1: 268-295.

Hoffmann, J. and Kurz, C. (2003) Rent Indices for Housing in West Germany 1985 to 1998 Discussion Paper 01/02, Economic Research Centre of the Deutsche Bundesbank: Frankfurt.

Holm-Müller, K., Hansen, H., Klockmann, M. and Luther, P. (1991) Die Nachfrage nach Umweltqualität in der Bundesrepublik Deutschland. Forschungsbericht 10103110/11, Umweltbundesamt: Berlin.

Hulme, D. and Shead, N. (1999) Climate Change Scenarios for Germany Climate Change Unit, University of East Anglia: Norwich. Available at: http://www.cru.uea.ac.uk/ mikeh/research/wwf.germany.pdf

Intergovernmental Panel on Climate Change (1998) The Regional Impacts of Climate Change: An Assessment of Vulnerability. A Special Report of IPCC Working Group II. Edited by Watson, R., Zinyowera, M., Moss, R. and Dokken, D. Cambridge University Press: Cambridge.

Intergovernmental Panel on Climate Change (2001) Impacts, Adaptation, and Vulnerability. Contribution of Working Group II to the Third Assessment Report of the Intergovernmental Panel on Climate Change Edited by McCarthy, J., Canziani, O., Leary, N., Dokken, D. and White, K. Cambridge University Press: Cambridge. 
Maddison, D. (2003) The Amenity Value of Climate: The Household Production Function Approach Resource and Energy Economics 25: 155-175.

Maddison, D. and Bigano, A. (2003) The Amenity Value of the Italian Climate Journal of Environmental Economics and Management 45: 319-332.

Michaels, R. and Smith, V. (1990) Market Segmentation and Valuing Amenities with Hedonic Models - The Case of Hazardous Waste Sites Journal of Urban Economics 28: 223242.

Mitchell, T., Carter, T., Jones, P., Hulme, M. and New, M. (2003) A Comprehensive Set of High-Resolution Grids of Monthly Climate for Europe and the Globe: The Observed Record (1901-2000) and 16 Scenarios (2001-2100) mimeo, Tyndall Centre: University of East Anglia.

Navrud, S. (1999) Report to EC-DGXI: Pilot Project to Assess Environmental Valuation Reference Inventory (EVRI) and the Expansion Its Coverage to the EU, Part II: List of European Valuation Studies Office for Official Publications of the European Community: Luxembourg.

Nordhaus, W. (1996) Climate Amenities and Global Warming. In Nakicenovic, N., Nordhaus, W., Richels, R. and Toth, F. (Eds.) Climate Change: Integrating Science, Economics, and Policy International Institute for Applied Systems Analysis: Laxenburg.

Palmquist, R. (1991) Hedonic Methods. In Braden, J. and Kolstad, C. (Eds.) Measuring the Demand for Environmental Quality Amsterdam: Elsevier.

Pearce, D., Achanta, A. Cline, W. Fankhauser, S. Pachauri, R., Tol R. and Vellinga, P. (1996) The Social Costs of Climate Change: Greenhouse Damage and the Benefits of Control. In Bruce, J. Lee, H. and Haites, E. (Eds.) Climate Change 1995: Economic and Social Dimensions of Climate Change - Contribution of Working Group III to the Second Assessment Report of the Intergovernmental Panel on Climate Change Cambridge University Press: Cambridge.

Roback, J. (1982) Wages, Rents and the Quality of Life Journal of Political Economy 90: 1257-1278.

Rosen, S. (1974) Hedonic Prices and Implicit Markets: Product Differentiation in Pure Competition Journal of Political Economy 82: 34-55.

Schnare, A. and Struyk, R. (1976) Segmentation in Urban Housing Markets Journal of Urban Economics 4: 146-166.

Straszheim, M. (1974) Hedonic Estimation of Housing Market Prices: A Further Comment Review of Economics and Statistics 56: 404-406. 
Statistisches Bundesamt Deutschland (1999) Mikrozensus 1999 Statistisches Bundesamt Deutschland: Stuttgart.

Statistisches Bundesamt Deutschland (2001) Statistik Regional: Daten für die Kreise und Kreisfreien Städte Deutschlands Statistisches Bundesamt Deutschland: Stuttgart.

Tol, R. (2002a) Estimates of the Damage Costs of Climate Change Part 1: Benchmark Estimates Environmental and Resource Economics 21: 47-73.

Tol, R. (2002b) Estimates of the Damage Costs of Climate Change: Part II. Dynamic Estimates Environmental and Resource Economics 21: 135-60. 